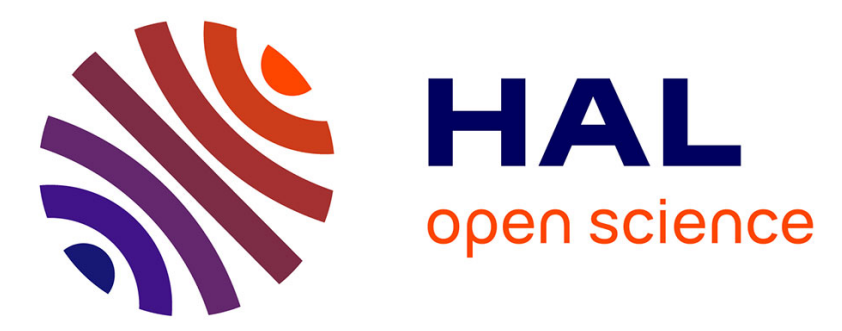

\title{
Oral lipolysis and its association with diet and the perception and digestion of lipids: A systematic literature review
}

\author{
Hélène Brignot, Gilles Feron
}

\section{To cite this version:}

Hélène Brignot, Gilles Feron. Oral lipolysis and its association with diet and the perception and digestion of lipids: A systematic literature review. Archives of Oral Biology, 2019, 108, pp.104550. 10.1016/j.archoralbio.2019.104550 . hal-02619465

\section{HAL Id: hal-02619465 \\ https://hal.inrae.fr/hal-02619465}

Submitted on 21 Dec 2021

HAL is a multi-disciplinary open access archive for the deposit and dissemination of scientific research documents, whether they are published or not. The documents may come from teaching and research institutions in France or abroad, or from public or private research centers.
L'archive ouverte pluridisciplinaire HAL, est destinée au dépôt et à la diffusion de documents scientifiques de niveau recherche, publiés ou non, émanant des établissements d'enseignement et de recherche français ou étrangers, des laboratoires publics ou privés.

\section{다)(1) $(5$}

Distributed under a Creative Commons Attribution - NonCommerciall 4.0 International 
1 Oral lipolysis and its association with diet and the perception and digestion of lipids: A

2 systematic literature review

\section{Hélène Brignot and Gilles Feron}

Centre des Sciences du Goût et de l'Alimentation, AgroSup Dijon, CNRS, INRA, Univ. Bourgogne Franche-Comté, F-21000 Dijon, France.

Corresponding author: Gilles Feron, INRA, CSGA, 17 rue Sully, F-21000 Dijon, France, Telephone: +33 3806932 78, E-mail address: gilles.feron@inra.fr

\section{Abstract}

Objectives: This systematic literature review aims to summarize the existing scientific evidence on the association of oral lipolysis with diet and with the perception and digestion of lipids in humans and rodents. Methods: A validated search strategy of two databases (PubMed and ISI Web of Knowledge) was carried out and the contents were screened by two independent reviewers. The quality of the included studies was critically evaluated on the basis of the Quality Assessment Criteria for Evaluating Primary Research Papers. Results: From the originally identified studies $(n=2295), 17$ articles met the eligibility criteria for inclusion in the analysis. Among them, only 6 articles received the maximum assessment score. The main reason for this finding was the absence of a control for the confounding bias between lipases and esterases. In rodents, oral lipolysis was principally due to the activity of lingual lipase, which was associated with the 3 selected parameters. In humans, the association parameters were principally established through indirect evidence without a clear demonstration of cause. Moreover, no specific lipase, such as lingual lipase in the case of rodents, was identified at the oral level. Conclusions: Future research efforts should focus on (i) establishing a standard procedure for oral lipolytic activity evaluation and, in 
particular, a methodological control to address the lipase vs esterase confounding bias and (ii) identifying the main lipases that contribute to the lipolytic activity in humans at the oral level and their respective contribution to the association parameters defined in this review.

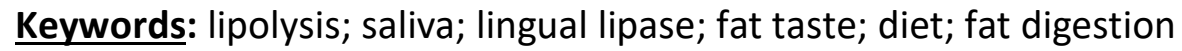

\section{Introduction}

Whole saliva is a complex mixture of fluids from major (parotid, submandibular, sublingual) and minor salivary glands (e.g., Von Ebner), gingival crevicular fluid, oral bacteria and food debris (Humphrey \& Williamson, 2001). Saliva is $99 \%$ water and contains numerous proteins, peptide metabolites and ions (Carpenter, 2013). Saliva contributes not only to the protection of mucosa against pathogens but also to the ability to taste, detect and digest macronutrients and micronutrients in food (Dawes et al., 2015). For instance, in the salt taste in humans, sensitivity is directly related to salivary sodium levels (Feron, 2018).

With respect to digestion, salivary alpha-amylases contribute to the hydrolysis and postprandial metabolism of complex carbohydrates (Joubert et al., 2017; Kurahashi \& Inomata, 1999; Lebenthal, 1987; Mandel \& Breslin, 2012).

Moreover, salivary alpha-amylases can adapt to the carbohydrate content of the diet (Squires, 1953). Recently, Perry et al. (2007) showed that populations with high starch diets have more copies of the salivary alpha-amylase gene (AMY1) than those with traditionally low-starch diets.

In regard to fats and other lipids, the role of salivary lipolysis in the oral detection and digestion of dietary fat in rodents was discovered (Kawai \& Fushiki, 2003; Sclafani \& Ackroff, 2018) with the identification and characterization of a lingual lipase secreted by Von Ebner 
glands (Hamosh \& Scow, 1973). In humans, lipolysis occurs in the oral cavity and may be substrate-specific (Lai, Chua, Gill, \& Brownlee, 2019). However, the role of oral cavity lipolysis in the detection and digestion of lipids is debated, with only indirect evidence showing that oral lipolysis has an impact on lipid detection (Feron \& Poette, 2013). Moreover, the involvement of specific lipases, i.e., gastric lipase, in oral lipolysis remains highly questionable.

In this context, the aim of this work was to review systematically original articles on studies of oral lipolysis and its association with diet and with the perception and with the digestion of lipids in humans and/or rodents.

\section{Materials and Methods}

\section{- Search strategy}

A review of the literature was conducted in May 2017 for all published articles containing information on the association between oral lipolysis and diet and the perception and digestion of lipids in humans and/or rodents.

The electronic databases PubMed and ISI Web of Knowledge were used to search for relevant articles without date restrictions. A regular search was updated until June 2019, and in this way, articles were added to the previous results.

Additionally, studies were identified from other sources (authors' literature base and the reference lists in the screened articles).

The search strategy consisted of a set of Medical Subject Headings (MeSH), and the terms and free text words were subsequently combined. The search terms were defined based on studies on the respective topics, keywords and the expertise of the working group members. The following groups of key words were used $(*$ indicates that the term was used as a 
wildcard to search for certain terms that might represent any group of words associated with these terms):

1) lipase*, lipolysis, lipolytic, (lipid* and hydrolysis), esterase;

2) oral, saliva, salivary, (saliva and gland), tongue, (buccal and mucosa), lingual, (oral and mucosa), (oral and (microbiota, microbiome, bacteria, and flora)), (buccal and (microbiota, microbiome, bacteria, and flora));

3) fat*, fatty*, (fatty and acid*), lipid*,oil*, (dietary fat*), triglyceride*, omega 3, omega 6, oleic, linoleic, linolenic, palmitoleic, stearic, palmitic, butyric, caprylic, lauric, myristic, arachidic, LCFA (long chain fatty acids), OR myristoleic OR vaccenic OR stearidonic OR gondoic OR arachid* OR behenic OR *pentaenoic OR erucic OR *hexanoic;

4) detection, digestion, perception, suckling, eating, feeding, consumption, intake, intensity, sensitivity, orosensitivity, liking, taste, flavour, preference, (taste and threshold); and

5) human, mice, rat, (guinea and pig), mammals.

Articles identified in the limited initial search were screened by title, abstract and full text following, whenever relevant, the PRISMA (Preferred Reporting Items for Systematic Reviews and Meta-Analyses) guidelines for systematic reviews (Moher, Liberati, Tetzlaff, Altman, \& Grp, 2009). Protocol and PRISMA checklist form (table S1) are presented in the supplementary material file.

\section{- Selection criteria}

Articles were included only if they explored an association between lipolysis in the oral cavity and one of the following characteristics: fat taste perception and/or digestion and/or 
diet in human subjects or rodents.

97 Only articles with abstracts (no proceedings papers or reviews) and written in English were included. There was no limitation on date. The study design and settings were not defined with exclusion criteria because of the exploratory character of this review.

Two reviewers (GF and $\mathrm{HB}$ ) independently screened titles and abstracts based on the selection criteria. If the abstract did not provide enough information to decide upon inclusion or exclusion, the full paper was retrieved for further screening.

\section{- Article extraction and synthesis}

Search database results were combined into a master reference database which is End Note X7 (Thomson Reuters) and duplicate references were deleted. Two reviewers (GF and HB) independently reviewed the initial list and compared selections, evaluating all against the pre-defined criteria. Reviews, proceedings papers and non-English articles were set aside manually. Variables for which data were sought were: control of specificity (lipase vs esterase), biological material, substrate of the lipase, $\mathrm{pH}$ and $\mathrm{T}^{\circ}$ of lipolysis measurement, methodology for lipolysis measurement (titrimetry, spectrophotometry, etc ..), model (human or rodent) and associated effect (lipid taste and preference, lipid digestion, lipid diet)

\section{- Quality assessment}

The quality assessment of the articles was adapted for this review based on, "The quality assessment criteria for evaluating primary research papers from a variety of fields" (Kmet, Cook, \& Lee, 2004). The checklist of criteria included the following questions:

1. Is the objective of the study sufficiently described?

2. Is the study design evident and appropriate?

3. Are the outcomes related to lipolysis evaluation well defined and robust with regard 
to the measurement(s) used? Was misclassification bias evident? Were the means of assessment reported?

4. Are the analytical methods described, justified and appropriate?

5. Is some estimate of variance reported for the main results?

6. Are the results reported in sufficient detail?

7. Are the conclusions supported by the results?

126 Each question represents a parameter of quality and can be answered with 'yes', 'partial', 'no' or 'not applicable'. A score of 1 was allocated to each parameter for rigorous studies

131

with high standards. A score of 0 was allocated to a parameter that was not described, was insufficiently described or was inadequately justified. Finally, a score of 0.5 was allocated to a parameter that was insufficiently described or inadequately justified.

The summary score for each review was calculated by the total sum ((number of 'yes' scores x 1) + (number of 'partial' scores $x 0.5)+($ number of 'no' or 'not applicable' scores $x 0)$ ) divided by total possible score (7).

\section{$\underline{\text { Results }}$}

\section{- Selected articles}

The overview of the search strategy is shown in figure 1.

In May 2017, a total of 2295 articles were identified: PubMed $(n=838)$ and ISI Web of Knowledge $(n=1457)$. Duplicate articles $(n=257)$ were excluded. Another 1940 articles were excluded because the inclusion criteria were not met (based on the title). Thus, the abstracts of 97 articles were screened.

Eighty articles were excluded based on the following unmet criteria in the abstract: not written in English ( $n=1)$, proceedings paper $(n=4)$, a review $(n=15)$, not on humans or rodents $(n=7)$, not on oral cavity or with no reference to lipolysis $(n=28)$, only sensory experiments 
144 are described $(n=1)$ or no associations with oral lipolysis (as described previously) $(n=24)$.

145 An alert in each database was created for backward citation chasing because of the delay in 146 writing. As a consequence of this approach, two new articles were found to be of interest for 147 this review and have been included. Moreover, two additional articles from sources other 148 than the databases were included. From these 21 articles, 4 articles were excluded after full 149 text screening for the following reasons: not in the oral cavity $(n=1)$ and not linked with 150 associated parameters ( $n=3$ ). The final group consisted of 17 articles (Table 1 ). All of them 151 were subjected to a methodological quality assessment.

\section{- Article quality evaluation}

153 The methodological quality of the included studies was judged to be good, in general.

154 Thirteen of the 17 selected articles had quality scores between 0.9 and 1 (Table 2).

155 The maximum score according to the abovementioned scoring procedure was attributed to 1566 articles (Besnard et al., 2018; Méjean et al., 2015; Mounayar, Septier, Chabanet, Feron, \& 157 Neyraud, 2013; Poette et al., 2014; Sclafani \& Ackroff, 2018; Voigt et al., 2014). The lowest 158 score of the list was attributed to one article (Stewart et al., 2010).

159 In all articles, the objectives were clearly explained, and each earned the maximum score on 160 the rating scale. Of the 17 articles, a score of 1 was given for the study design and the

161 analytical methods for 13 and 14 articles, respectively.

162 In 11 articles, oral lipolysis evaluations (main outcome) are well defined and robust 163 according to the measurements without misclassification bias and with means of assessment 164 reported. In 6 articles, oral lipolysis evaluation did not meet all the requirements necessary 165 to earn the maximum score. The main reason for submaximal scoring was the absence of an 166 analytical procedure, i.e., an appropriate inhibitor of lipase or esterase was not chosen for 167 discriminating between lipase and esterase activity. 
For 4 articles, the score for "results reported in sufficient detail" did not reach the maximum possible. This lower score was attributed to papers that lacked a table showing the results with standard deviation values of the oral lipolysis measured, or detailed lipolytic activity data were not provided.

Finally, 5 articles showed conclusions that were not fully supported by the results, essentially due to the absence of robust statistical analysis.

\section{- Study characteristics}

Seven of the selected articles were published after 2010 (table 1), and only 4 of them were published before 1990. Therefore, most of the selected studies were carried out recently.

Humans were used as the system model in the studies described in 11 articles (table 3), and people with obesity had been recruited in 4 of the 11 articles.

Six other articles were based on rodent studies. Among these, five studies had focused on rats, and one had focused on mice.

\section{- Analytical methods for lipolysis evaluation}

Oral lipolysis was either determined or evaluated across all the selected studies (Table 3). The studies differed by approach (in vitro or in situ), the control(s) (specificity), the condition(s) of measurement and/or the substrate.

\section{- Control for lipase specificity}

Lipases and esterases belong to the same enzyme classification group EC 3.1.1: carboxylic ester hydrolases. However, unlike esterases, lipases have substrate specificity towards fatty acid esters (i.e., mono-, di-, tri-glycerides) and preferences for medium (C8 to C14) and long (C>16) chains because of their insolubility in polar media (Robb, 1966). Thus, a control for specificity, which eliminates the case of esterase activity, leads to the selection of only lipase activity measurements. A inhibitor of lipase activity is THL (Tiss, Lengsfeld, Carriere, \& 
192 193 194 195 papillae from collected tongues.

\section{- Approaches}

\section{$\underline{\text { In vitro measures }}$}

Verger, 2009), which was used in the studies described in 11 articles. In one case (Mennella, Fogliano, \& Vitaglione, 2014), the control consisted of adding $0.4 \mathrm{mM}$ PMSF to inhibit esterase activity to quantify the lipase activity - the 2 enzymes acted on the same substrate (Kurooka, Okamoto, \& Hashimoto, 1977). Contrary to applications for THL, PMSF is used to measure lipase activity after esterase activity is suppressed. Indeed, it was demonstrated that PMSF inhibits acetylcholine esterases (EC 3.1.1.7) of brain and hepatic serum origin (Fahrney \& Gold, 1963; Turini, Kurooka, Steer, Corbascio, \& Singer, 1969); the type B carboxylesterases are in the brain, and the aryl esterases (EC 3.1.1.2), which belong in the type A carboxylesterase classification, are in hepatic serum (Kurooka et al., 1977). The mechanism of inhibition involves the binding of PMSF to the active site of the esterase (Fahrney \& Gold, 1963). Nevertheless, it has not been proven that PMSF inhibits the esterase activity in the oral cavity; for example, saliva contains other esterases, such as carbonic anhydrases (EC 4.1.1.2), in abundance, and bacterial esterase, which could not be inhibited by PMSF and could not have the same active site. Thus, in the attempt to control for the confounding effects of esterase and lipase activity, this indirect method presents more limitations than are presented by methods that use THL to measure lipolytic activity.

Measurements described in 13 articles were taken from experiments performed in vitro. Among them, the biological material was free saliva except in three: Armand et al. (1990) and Hamosh (1978), in which the posterior part of the lingual tissue was collected, and Kawai \& Fushiki (2003) in which measurements was conducted on exposed circumvallate

In Hamosh and Scow (1973), two types of biological materials were tested, i.e., free saliva 
216 and tissue from the white tissue of the tongue in the region of circumvallate papillae which

217 consists of serous lingual (Von Ebner) glands and secretory ducts and various other parts of

218 the oral cavity.

219 Whole saliva was used in the oldest studies (Hamosh \& Scow, 1973; Plucinski, Hamosh, \&

220 Hamosh, 1979), and clarified saliva was used in the papers published in the past 10 years.

221 Whole saliva was frozen directly after collection, whereas clarified saliva was obtained after

222 centrifugation at $14000 \mathrm{~g}$ for 10 to 20 minutes at $4^{\circ} \mathrm{C}$ (Neyraud, Palicki, Schwartz, Nicklaus,

223 \& Feron, 2012). Indeed, pre-treatment standardization has become common practice

224 because the current techniques, such as fluorometry, require homogeneous micro volume

225 samples without large particles (Schipper, Silletti, \& Vingerhoeds, 2007).

226 Saliva was collected according to the objective of the studies in stimulated or unstimulated

227 conditions. The stimulation was mechanical (Besnard et al., 2018) or was conferred by cream

228 consumption and rinsing (Stewart et al., 2010). Four articles used only unstimulated saliva as

229 biological material, 3 articles used unstimulated and stimulated saliva and three articles used

230 only stimulated saliva.

231 Evaluation in situ

232 Four studies were conducted in situ. Two studies measured lipase activity. In one case, the

233 substrate was placed on filter disk paper, and the amount of non-esterified fatty acids

234 released was measured in situ at the proximity of the secretory glands (Von Ebner gland

235 cells) (Voigt et al., 2014).

236 An alternative method that did not clearly measure lipase activity measured the non-

237 esterified fatty acids released from a natural and high-fat food matrix in an expectorated

238 food bolus (Kulkarni \& Mattes, 2014).

239 Instead of the direct biochemical method described above, indirect evaluation of the role of 
240 lipolytic activity was measured by taste sensitivity to triolein in humans (Pepino, Love-

241 Gregory, Klein, \& Abumrad, 2012) or a preference for corn, soybean or triolein oil by rodents 242 (Sclafani \& Ackroff, 2018); both studies conducted experiments in the presence or absence 243 of THL.

- Conditions of measurement

245 The measurement of lipolytic activity was made using the following techniques alone or in 246 combination:

247 - Measurements of the $\mathrm{pH}$ variations due to the release of fatty acids from triglycerides 248 by the lipolytic reaction: the $\mathrm{pH}$-stat method was used with a method derived from 249 Taylor (1985), and the results were established through titrimetry. 1977).

- Substrates used for evaluation of lipolytic activity

254 The substrates used for measuring lipolytic activity were diglycerides (in 1 article only), 255 natural triglycerides from food, synthetic triglycerides, radiolabelled triglycerides or 256 synthetic free fatty acid esters. The chain length of the fatty acid substrates ranged from 4 to 25718 carbons, and oleic acid was often used. Notably, the use of long-chain triglycerides 258 enabled better activity quantification of the lipolytic reaction mechanism.

259 In the selected publications, we did not find any information about the degree of substrate 260 emulsification that affects interface development for micelle formation, which is a 261 determinant of lipase activity (Verger, 1997). 
Most of the reactions were carried out at $\mathrm{pH} 7$, including those carried out (i) with saliva,

263 which is considered to have a pH of approximately 7 (Schipper et al., 2007), (ii) in a food

264 bolus ( 1 article), and (iii) fixed onto a matrix (filter disks) (2 articles).

265 The determination of the optimal $\mathrm{pH}$ for lipase activity enables the differentiation of the

266 lipases that act directly at oil-water interface (e.g., acid-like gastric lipases) from the lipases

267 that act on micellar structures with the required biliary salts (e.g., pancreatic lipases)

268 (Eydoux et al., 2007; Lombardo, Fauvel, \& Guy, 1980). The pH at which the measurements 269 were taken shows that salivary lipases act as acidic lipases in acidic and neutral 270 environments at oil-water interfaces.

- Oral lipolysis and association parameters (diet, digestion and taste) (Table 4)

273 Four publications were identified as describing a link between diet and oral lipolysis. Two

274 were conducted on rats with the objective of evaluating the effect of a fat-related diet on 275 the level of lingual lipase (Armand et al., 1990; Hamosh, 1978). Both papers reached the 276 same conclusion, i.e., increasing the fat content in the diet led to an increase in lingual lipase 277 activity in a dose-dependent response, suggesting an adaptive response to the level of fat in 278 the diet.

279 In addition, 2 other papers focused on the relationships between salivary lipolysis and fat 280 preference and intake in humans. These papers reached contradictory conclusions. 281 Mennella et al. (2014) observed higher lipolytic activity, fat preference and fat intake in 282 overweight subjects compared with lean subjects. The authors suggest that high salivary 283 lipolytic activity in overweight subjects could be an adaptive response to low-fat taste 284 perception due to a low level of salivary zinc. In contrast, Méjean et al. (2015) did not 285 identify relationships between salivary lipolytic activity on one hand and fat preferences and 
intake on the other hand, regardless of BMI. These discrepancies in the results can be

explained by (i) the populations differing significantly between the two studies in terms of age, sex and BMI, and (ii) the methodology used to evaluate salivary lipolytic activity in saliva and, in particular, the controls for the specificity of the reaction, which differed between the two studies, i.e., THL was used in the study by Mejean et al. and PMSF was used in the study by Mennella et al., which could have led to different estimations of lipolysis activity, as explained previously.

\section{- Relationships with digestion and metabolism}

294 Three papers described the role of oral lipolysis in lipid digestion and/or metabolism. Two studies were conducted on rats, and only one showed direct evidence of lipid digestion in the stomach, duodenum and ileum due to lingual lipase activity (Hamosh \& Scow, 1973).

297 Another study found that lingual lipase is $\mathrm{pH}$-dependent and remains active in the stomach 298 (Plucinski et al., 1979), which suggests that it can contribute to lipid digestion in this 299 compartment.

300 Only one study was conducted on humans (Vors et al., 2015). It described significant 301 associations between the level of stimulated salivary lipolysis and explained the post302 prandial lipaemia profile after fat intake depended on BMI. In particular, obese subjects 303 showed lower salivary lipolysis activity and a delay in post-prandial lipaemia compared with 304 lean subjects. The authors suggested that this lower level of salivary lipolysis in obesity can 305 impair lipid detection in the mouth and thus lead to lipaemia.

307 Ten studies were aimed at evaluating the role of oral lipolysis on taste of and preference for 308 fat. Two studies were conducted on rodents (rats or mice) in situ (Kawai \& Fushiki, 2003; 309 Sclafani \& Ackroff, 2018). In both studies, the inhibition of oral lipolysis by THL led to a 
decrease in fat preference, indirectly indicating the role of lingual lipase in the release of

311 free fatty acids from dietary fat such that they could be detected at the oral level.

312 Eight studies were conducted with humans. Three studies were conducted in situ by using

313 THL for the control of oral lipolysis (Kulkarni \& Mattes, 2014; Pepino et al., 2012; Voigt et al., 314 2014). The other 5 studies evaluated oral lipolysis in saliva samples in vitro. A control for 315 specificity was included in 6 experiments using THL. With respect to sensory evaluation, 7 studies evaluated taste sensitivity to triolein (in situ only) or to free fatty acids (mostly C18:2). One study evaluated the preference intensity ratings for fat emulsion (Neyraud et al., 2012). Two of the three studies conducted in situ showed an inhibition of triolein sensitivity in the presence of THL, which provides indirect evidence that oral lipolysis is involved in the detection of dietary fat in humans. Studies conducted in vitro have led to contradictory

321 conclusions. Two of them showed a positive correlation between the level of lipolysis in 322 saliva and fat sensitivity (Neyraud et al., 2012; Poette et al., 2014), while two others did not 323 find a statistical correlation (Besnard et al., 2018; Mounayar et al., 2013).

\section{Discussion}

325 In this work, two aspects were considered. In the first part, we considered the methods used 326 for lipase measurements and evidence gathered by functional testing. In the second part, we 327 focused on different associations with oral lipolysis, i.e., taste sensitivity, digestion and diet.

\section{- Methodological considerations}

329 One main conclusion of this SLR is that the methods used were diverse and heterogeneous 330 for evaluating oral lipolysis, which made comparing the different papers difficult, particularly 331 the comparisons of study results that were published by different research groups.

332 This challenge to the comparisons led to the determination of a standardized protocol for 333 the evaluation of lipolytic activity with different constraints. 
334 First, the measurements for lipolytic activity aimed to take into account enzymatic 335 specificity. Among the various controls used to overcome the confounding results from 336 esterase and lipase activity, the most relevant method involved measures with and without 337 THL. The robustness of inhibition by THL (Luthipeng, Marki, \& Hadvary, 1992) is due to 338 covalent binding to the active site, which consists of a catalytic triad formed by the serine, 339 aspartate, and histidine that are characteristic of the lipase family, that inactivates the 340 lipases (Beer, Wohlfahrt, McCarthy, Schomburg, \& Schmid, 1996); these binding sites are not 341 present in esterases (Chahinian \& Sarda, 2009). This difference explains why THL is highly 342 discriminant, as has been demonstrated in the case of digestive lipases (Ransac et al., 1997). 343 Second, the choice of substrate enabled specific lipases to be targeted for study. The fatty 344 acid chain length is primordial, and medium (from C8 to C14) or long chain (>C16) fatty acid 345 glycerides are used as substrates, although the long-chain fatty acid glycerides are difficult to 346 solubilize. Foremost, researchers compromised between using natural or radiolabelled 347 triglycerides and synthetic esters, such as 4-methylumbelliferyl-oleate, which are less 348 specific but safer and faster for detecting and quantifying. Furthermore, substrates in the 349 form of micelles in aqueous medium ensure an optimal interface (Paiva, Balcão, \& Malcata, 350 2000) for lipase reactions. Thus, the conditions were adapted to study weak lipase activity, 351 as is the case for salivary lipases.

352 Third, evaluation of lipolysis activity was performed at fixed $\mathrm{pH}$, and some studies conducted 353 experiments at non-physiological pH levels. Additionally, no measurement method for 354 screening several $\mathrm{pH}$ values was used, which means that the lipases could not be 355 differentiated.

356 Finally, sample standardization is preferable in the case of salivary analysis. Clarified saliva 357 samples with a fixed protocol were described in 6 studies (Méjean et al., 2015; Mounayar et 

adapted for use in these types of analyses.

In summary, a literature review (Beisson et al., 2001) described the screening assays for quantifying lipase activity on the principles and practical aspects of this methodological consideration. It was concluded that the $\mathrm{pH}$-stat method, which enabled screening over an extended range of $\mathrm{pH}$ values due to the inclusion of several $\mathrm{pH}$ indicators, is suitable for pure lipase assays, and a method based on natural fluorescent substrates, as described in Beisson et al. 1999, is more suitable for crude biological sample assays (Beisson et al., 1999). Recently, a more sensitive method than the original pH-stat has been developed (Camacho-

367 Ruiz, Mateos-Diaz, Carriere, \& Rodriguez, 2015). Interestingly, both methodologies are 368 appropriate for screening a large number of biological samples.

\section{- Oral lipolysis and the association parameters}

371 Lingual lipase was notably involved in salivary lipolysis in rats and mice. It is secreted from

372 the serous glands found on the dorsal tongue (Hamosh, 1978; Hamosh \& Scow, 1973;

373 Triantafyllou, Fletcher, \& Scott, 2003) and has a high level of activity compared with gastric 374 lipase (DeNigris, Hamosh, Kasbekar, Lee, \& Hamosh, 1988). Rat lingual lipase has a molecular 375 weight of $270000-300000$, which suggests extensive self-aggregation, and it is active from $376 \mathrm{pH} 2$ to 8 . Its activity is not influenced by the concentration levels of phospholipids or bile 377 salts, and therefore it differs significantly from the pancreatic lipases (Roberts, Montgomery, 378 \& Carey, 1984). In contrast to that in rats, lingual lipase has never been clearly demonstrated 379 in humans, and attempts to identify its secretion at the serous gland level have always failed 380 (Spielman, D'Abundo, Field, \& Schmale, 1993; Voigt et al., 2014). Hence, it is likely that 381 salivary lipolysis is due to the activity of other lipases. Indeed, the expression of putative 
secreted lipolytic enzymes has been shown in human Von Ebner gland cells (Voigt et al., 2014).

- Adaptation of salivary lipolysis to diet lipid content and quality

The adaptation of salivary properties to the human diet has been clearly established on salivary alpha-amylase activity and carbohydrate consumption, i.e., the level of salivary alpha-amylase is higher, and the consumption of complex carbohydrates is higher in the diet (Squires, 1953). More recently, the number of gene copies of salivary alpha-amylase (AMY1) has been associated with a starch diet in a way that aligns with the findings from the diet studies (Perry et al., 2007) but it is also associated with BMI such that a low AMY1 copy number is associated with a high BMI (Falchi et al., 2014). With respect to lipids in the diet and lingual lipase activity, few papers have suggested salivary adaptation in rodents, but the conclusions are consistent between studies. In contrast, no clear conclusions could be made on salivary adaptation in humans, which is a topic that warrants further attention.

\section{- Role of salivary lipolysis in fat perception and digestion}

Both in rodents and humans, only indirect evidence suggests a contribution of salivary lipolysis to the orosensory detection of fat. Indeed, salivary lipases hydrolyse triglyceride, and the resulting free fatty acids can be detected by putative fat sensors, such as the CD36 fatty acid transporter, which is involved in the detection of long chain fatty acids at the taste bud level in rodents (Laugerette et al., 2005). In humans, it has been shown that oronasal exposure to dietary fat can influence post-prandial metabolism, particularly the stimulation of lipid digestion and absorption (Mattes, 1996, 2011). With respect to taste, the oral fatty acid threshold measurement of different long chain fatty acids showed that they are perceived through the taste modality only (Chale-Rush, Burgess, \& Mattes, 2007), but whether sensors, such as CD36, are involved in long chain fatty acid detection is still 
debated. However, both in rodents and humans, the contribution of salivary lipolysis to the

407 modulation of oral fat perception is merely speculative. Moreover, factors not involved in 408 lipolysis, namely, lipocalin or carbonic anhydrase $\mathrm{VI}$, have been proposed as other putative 409 salivary components that are involved in the modulation of free fatty acid perception 410 (Besnard et al., 2018; Feron \& Poette, 2013). Unravelling the mechanism by which salivary 411 lipolysis impacts fat detection at the oral level should be studied further.

412 With respect to digestion, lingual lipase participates in digesting as much as $6 \%$ of the lipids 413 during the oral phase in rats (Kawai \& Fushiki, 2003). Compared with triglycerides, 414 diglycerides might be more easily digested by lingual lipase, suggesting a different substrate 415 specificity compared with other lipases of the digestive tract (Osaki et al., 2005). In contrast 416 to that in rats, the level of salivary lipolysis activity in humans is such that it cannot 417 contribute to dietary fat digestion. However, as suggested by Vors et al., 2015, a low level of 418 salivary lipolysis could indirectly contribute to lipid metabolism in humans through the 419 release of a small amount of free fatty acids that are detected in the mouth and thus 420 stimulate anticipatory digestive and metabolic responses for lipids prior to nutrient 421 absorption. Such a mechanism has been proposed for salivary alpha-amylase, as subjects 422 with a higher level of salivary alpha-amylase showed a lower level of post-prandial glucose 423 concentrations after oral intake of a starch load (Mandel \& Breslin, 2012). The authors 424 suggested that the production and detection of glucose and/or maltose and/or short-chain 425 oligosaccharides through amylolytic activity in the oral cavity signals the body to prepare for 426 incoming starch and the ensuing glucose.

\section{$427 \quad$ Limitations of this SLR}

428 A bias cannot be excluded in the selection phase. First, it is possible that not all relevant 429 studies are indexed in the searched databases (ISI Web of Knowledge and PubMed). Second, 
the search was based on a list of terms describing the potential association of oral lipolysis

431 with different parameters. The possibility that additional articles would have been identified 432 by adding other terms cannot be excluded; although the search was intended to be as 433 extensive as possible. Third, article eligibility was restrictive. We chose to include papers on 434 oral lipolysis and specific parameters associated with it. This criterion created a restraint that 435 limited our analysis and such an investigation conducted on oral lipolysis outcome was only expected to substantiate and enlarge our conclusions. Fourth, in this review, only studies in English were included, which could have led to biased conclusions. However, it is noteworthy that only one study was excluded for language; therefore, the bias was presumably low. Finally, we chose to include studies submitted to a peer review procedure, which could have limited the results through publication bias. Indeed, studies with positive

441 results tend to be selected for publication.

\section{Conclusion}

443 With respect to methodological considerations, this SLR highlights the fact that a consensus 444 for a normative method to evaluate lipase activity is highly necessary. This methodology 445 must be based on considerations for both specificity (lipase versus esterase substrates) and $446 \mathrm{pH}$ measurements. It will also need to be suitable for high output screening of small volume 447 biological samples. Regarding the associations studied (diet, digestion or taste), this SLR highlights the small number of papers that address salivary lipolysis either in animal models 449 or in humans. In fact, most of the studies conducted in humans or animals focused on the 450 mechanisms leading to lipid and free fatty acid detection rather than on those involved in 451 upstream or peri-receptor biological events. This finding was unexpected in light of the 452 considerable controversy and debate around oral lipolysis and its role in humans. 
453 In contrast to animal lingual lipase, human oral lipases could not be identified with specificity

454 associated with lipid detection, digestion or diet. Moreover, no proteomic studies have been 455 published with conclusions that confirm or dispute the presence of a human lingual lipase. It 456 is likely that in humans, different lipases such as from bacteria are involved in the overall 457 salivary lipolysis activity, rendering any relationships with physiological effects and diet 458 difficult to discern, which explains the extensive discrepancies observed in the literature on 459 this scientific subject.

\section{Acknowledgments:}

461 This work was supported by grants from the Conseil Régional Bourgogne, Franche-Comte 462 (PARI grant) and the FEDER (European Funding for Regional Economical Development).

\section{Conflicts of interest}

464 The authors state no conflicts of interest

\section{References}

466 Armand, M., Borel, P., Cara, L., Senft, M., Chautan, M., Lafont, H., \& Lairon, D. (1990). 467 Adaptation of lingual lipase to dietary fat in rats. Journal of Nutrition, 120(10), 11481156. doi:10.1093/jn/120.10.1148

Beer, H. D., Wohlfahrt, G., McCarthy, J. E. G., Schomburg, D., \& Schmid, R. D. (1996). Analysis of the catalytic mechanism of a fungal lipase using computer-aided design and structural mutants. Protein Engineering, 9(6), 507-517. doi:10.1093/protein/9.6.507

472 Beisson, F., Aoubala, M., Marull, S., Moustacas-Gardies, A. M., Voultoury, R., Verger, R., \& Arondel, V. (2001). Use of the tape stripping technique for directly quantifying esterase activities in human stratum corneum. Analytical Biochemistry, 290(2), 179185. doi: $10.1006 / a b i o .2000 .4977$ 
476 Beisson, F., Ferte, N., Nari, J., Noat, G., Arondel, V., \& Verger, R. (1999). Use of naturally

477

478

479

480

481

482

483

484

485

486

487

488

489

490

491

492

493

494

495

496

497

498

499 fluorescent triacylglycerols from Parinari glaberrimum to detect low lipase activities from Arabidopsis thaliana seedlings. Journal of Lipid Research, 40(12), 2313-2321.

Besnard, P., Christensen, J. E., Brignot, H., Bernard, A., Passilly-Degrace, P., Nicklaus, S., . . . Burcelin, R. (2018). Obese subjects with specific gustatory papillae microbiota and salivary cues display an impairment to sense lipids. Scientific Reports, 8(1), 6742. doi:10.1038/s41598-018-24619-1

Camacho-Ruiz, M. D., Mateos-Diaz, J. C., Carriere, F., \& Rodriguez, J. A. (2015). A broad pH range indicator-based spectrophotometric assay for true lipases using tributyrin and tricaprylin. Journal of Lipid Research, 56(5), 1057-1067. doi:10.1194/jlr.D052837

Carpenter, G. (2013). The secretion, components, and properties of saliva. Annual review of food science and technology, 4, 267-276. doi: 10.1146/annurev-food-030212-182700

Chahinian, H., \& Sarda, L. (2009). Distinction between esterases and lipases: comparative biochemical properties of sequence-related carboxylesterases. Protein and Peptide Letters, 16(10), 1149-1161. doi: 10.2174/092986609789071333

Chale-Rush, A., Burgess, J. R., \& Mattes, R. D. (2007). Evidence for human orosensory (taste?) sensitivity to free fatty acids. Chemical Senses, 32(5), 423-431. doi: 10.1093/chemse/bjm007

Dawes, C., Pedersen, A., Villa, A., Ekström, J., Proctor, G., Vissink, A., . . Narayana, N. (2015). The functions of human saliva: a review sponsored by the world workshop on oral medicine VI. Archives of Oral Biology, 60(6), 863-874. doi: 10.1016/j.archoralbio.2015.03.004

DeNigris, S. J., Hamosh, M., Kasbekar, D. K., Lee, T. C., \& Hamosh, P. (1988). Lingual and gastric lipases: species differences in the origin of prepancreatic digestive lipases and 

in the localization of gastric lipase. Biochimica et Biophysica Acta (BBA) - Lipids and Lipid Metabolism, 959(1), 38-45. doi: 10.1016/0005-2760(88)90147-6

Eydoux, C., De Caro, J., Ferrato, F., Boullanger, P., Lafont, D., Laugier, R., . . . De Caro, A. (2007). Further biochemical characterization of human pancreatic lipase-related protein 2 expressed in yeast cells. Journal of Lipid Research, 48(7), 1539-1549. doi:10.1194/jlr.M600486-JLR200

Fahrney, D. E., \& Gold, A. M. (1963). Sulfonyl fluorides as inhibitors of esterases .1. Rates of reaction with acetykcholinesterase, alpha-chymotrypsin, and trypsin. Journal of the American Chemical Society, 85(7), 997-\&. doi:10.1021/ja00890a037

Falchi, M., Moustafa, J. S. E.-S., Takousis, P., Pesce, F., Bonnefond, A., Andersson-Assarsson, J. C., . . Bottolo, L. (2014). Low copy number of the salivary amylase gene predisposes to obesity. Nature genetics, 46(5), 492-497. doi: 10.1038/ng.2939

Feron, G. (2018). Unstimulated saliva: background noise in taste molecules. Journal of texture studies. doi: 10.1111/jtxs.12369

Feron, G., \& Poette, J. (2013). In-mouth mechanism leading to the perception of fat in humans: from detection to preferences. The particular role of saliva. Oilseeds and fats, Crops and Lipids, 20(2), doi: 10.1051/ocl.2012.0496

Hamosh, M. (1978). Rat lingual lipase: factors affecting enzyme activity and secretion. American Journal of Physiology, 235(4), E416-421. doi: 10.1152/ajpendo.1978.235.4.E416

Hamosh, M., \& Scow, R. O. (1973). Lingual lipase and its role in the digestion of dietary lipid. Journal of Clinical Investigation, 52(1), 88-95. doi:10.1172/jci107177 
522 Humphrey, S. P., \& Williamson, R. T. (2001). A review of saliva: Normal composition, flow, and function. The Journal of Prosthetic Dentistry, 85(2), 162-169. doi: 10.1067/mpr.2001.113778

525

Imamurra, S. (1989). An enzymatic method using 1,2 diglyceride for pancreatic lipase test in serum. Clinical Chemistry, 35(1126).

Joubert, M., Septier, C., Brignot, H., Salles, C., Panouillé, M., Feron, G., \& Tournier, C. (2017). Chewing bread: impact on alpha-amylase secretion and oral digestion. Food \& Function, 8, 607-614. doi:10.1039/C6FO00963H

Kawai, T., \& Fushiki, T. (2003). Importance of lipolysis in oral cavity for orosensory detection of fat. American Journal of Physiology - Regulatory Integrative and Comparative Physiology, 285(2), R447-454. doi:10.1152/ajpregu.00729.2002

Kmet, L. M., Cook, L. S., \& Lee, R. C. (2004). Standard quality assessment criteria for evaluating primary research papers from a variety of fields. Retrieved from https://era.library.ualberta.ca/items/48b9b989-c221-4df6-9e35-af782082280e website: doi: 10.7939/R37M04F16

Kulkarni, B. V., \& Mattes, R. D. (2014). Lingual lipase activity in the orosensory detection of fat by humans. American Journal of Physiology - Regulatory Integrative and Comparative Physiology, 306(12), R879-885. doi:10.1152/ajpregu.00352.2013

Kurahashi, M., \& Inomata, K. (1999). Effects of dietary consistency and water content on parotid amylase secretion and gastric starch digestion in rats. Archives of Oral Biology, 44(12), 1013-1019. doi: 10.1016/S0003-9969(99)00099-0

Kurooka, S., Okamoto, S., \& Hashimoto, M. (1977). A novel and simple colorimetric assay for human serum lipase. Journal of Biochemistry, 81(2), 361-369. doi: 10.1093/oxfordjournals.jbchem.a131467 
Lai, W. Y. W., Chua, J. W. M., Gill, S., \& Brownlee, I. A. (2019). Analysis of the lipolytic activity of whole-saliva and site-specific secretions from the oral cavity of healthy adults. Nutrients, 11(1), 191. doi: 10.3390/nu11010191

Laugerette, F., Passilly-Degrace, P., Patris, B., Niot, I., Febbraio, M., Montmayeur, J.-P., \& Besnard, P. (2005). CD36 involvement in orosensory detection of dietary lipids, spontaneous fat preference, and digestive secretions. Journal of Clinical Investigation, 115(11), 3177-3184. doi: 10.1172/JCI25299

Lebenthal, E. (1987). Role of salivary amylase in gastric and intestinal digestion of starch. Digestive Diseases and Sciences, 32(10), 1155-1157. doi: 10.1007/BF01300204

Lombardo, D., Fauvel, J., \& Guy, O. (1980). Studies on the substrate specificity of a carboxyl ester hydrolase from human pancreatic juice. I. Action on carboxyl esters, glycerides and phospholipids. Biochimica et Biophysica Acta (BBA) - Enzymology, 611(1), 136146. doi: 10.1016/0005-2744(80)90049-2

Luthipeng, Q. Q., Marki, H. P., \& Hadvary, P. (1992). Identification of the active-site serine in human pancreatic lipase by chemical modification with tetrahydrolipstatin. FEBS Letters, 299(1), 111-115. doi:10.1016/0014-5793(92)80112-t

Mandel, A. L., \& Breslin, P. A. S. (2012). High endogenous salivary amylase activity Is associated with improved glycemic homeostasis following starch ingestion in adults. Journal of Nutrition, 142(5), 853-858. doi:10.3945/jn.111.156984

Mattes, R. D. (1996). Oral fat exposure alters postprandial lipid metabolism in humans. Physiology \& Behaviour, 63(6), 911-917. doi: 10.1093/ajcn/63.6.911

Mattes, R. D. (2011). Oral fatty acid signaling and intestinal lipid processing: Support and $\begin{array}{llll}\text { supposition. } \quad \text { Physiology } \quad \text { B } \quad \text { Behavior, } & \text { 105(1), }\end{array}$ doi:10.1016/j.physbeh.2011.02.016 
Méjean, C., Morzel, M., Neyraud, E., Issanchou, S., Martin, C., Bozonnet, S., . . Feron, G. (2015). Salivary composition Is associated with liking and usual nutrient intake. PloS one, 10(9), e0137473. doi: 10.1371/journal.pone.0137473

Mennella, I., Fogliano, V., \& Vitaglione, P. (2014). Salivary lipase and amylase activities are higher in overweight than in normal weight subjects: Influences on dietary behavior. Food Research International, 66, 463-468. doi:10.1016/j.foodres.2014.10.008

Moher, D., Liberati, A., Tetzlaff, J., Altman, D. G., \& Grp, P. (2009). Preferred reporting items for systematic reviews and meta-analyses: the PRISMA statement. PLoS Medicine, 6(7). doi:10.1371/journal.pmed.1000097

Mounayar, R., Septier, C., Chabanet, C., Feron, G., \& Neyraud, E. (2013). Oral fat sensitivity in humans: links to saliva composition before and after stimulation by oleic acid. Chemosensory Perception, 6(3), 118-126. doi:10.1007/s12078-013-9152-1

Neyraud, E., Palicki, O., Schwartz, C., Nicklaus, S., \& Feron, G. (2012). Variability of human saliva composition: possible relationships with fat perception and liking. Archives of Oral Biology, 57(5), 556-566. doi:10.1016/j.archoralbio.2011.09.016

Osaki, N., Meguro, S., Yajima, N., Matsuo, N., Tokimitsu, I., \& Shimasaki, H. (2005). Metabolites of dietary triacylglycerol and diacylglycerol during the digestion process in rats. Lipids, 40(3), 281-286. doi:10.1007/s11745-005-1383-3

Paiva, A. L., Balcão, V. M., \& Malcata, F. X. (2000). Kinetics and mechanisms of reactions catalyzed by immobilized lipases. Enzyme and Microbial Technology, 27(3), 187-204. doi: 10.1016/S0141-0229(00)00206-4

Pepino, M. Y., Love-Gregory, L., Klein, S., \& Abumrad, N. A. (2012). The fatty acid translocase gene CD36 and lingual lipase influence oral sensitivity to fat in obese subjects. Journal of Lipid Research, 53(3), 561-566. doi:10.1194/jlr.M021873 
594 Perry, G. H., Dominy, N. J., Claw, K. G., Lee, A. S., Fiegler, H., Redon, R., . . . Stone, A. C. 595 (2007). Diet and the evolution of human amylase gene copy number variation. Nature genetics, 39(10), 1256-1260. doi: 10.1038/ng2123

597 Plucinski, T. M., Hamosh, M., \& Hamosh, P. (1979). Fat digestion in rat: role of lingual lipase.

598

599

600

601

602

603

604

605

606

607

608

609

610

611

612

613

614

615 American Journal of Physiology, 237(6), E541-547. doi: 10.1152/ajpendo.1979.237.6.E541

Poette, J., Mekoue, J., Neyraud, E., Berdeaux, O., Renault, A., Guichard, E., . . . Feron, G. (2014). Fat sensitivity in humans: oleic acid detection threshold is linked to saliva composition and oral volume. Flavour and Fragrance Journal, 29(1), 39-49. doi:10.1002/ffj.3177

Ransac, S., Gargouri, Y., Marguet, F., Buono, G., Beglinger, C., Hildebrand, P., . . Verger, R. (1997). [10] Covalent inactivation of lipases. In B. Rubin, \& E. A. Dennis (Eds), Methods in Enzymology (Vol. 286, pp. 190-231). San Diego: Academic Press.

Robb, I. (1966). Determination of the aqueous solubility of fatty acids and alcohols. Australian Journal of Chemistry, 19(12), 2281-2284. doi: 10.1071/CH9662281

Roberts, I. M., Montgomery, R. K., \& Carey, M. C. (1984). Rat lingual lipase: partial purification, hydrolytic properties, and comparison with pancreatic lipase. American Journal of Physiology-Gastrointestinal and Liver Physiology, 247(4), G385-G393. doi: 10.1152/ajpgi.1984.247.4.G385

Schipper, R. G., Silletti, E., \& Vingerhoeds, M. H. (2007). Saliva as research material: Biochemical, physicochemical and practical aspects. Archives of Oral Biology, 52(12), 1114-1135. doi: 10.1016/j.archoralbio.2007.06.009 
616

Sclafani, A., \& Ackroff, K. (2018). Role of lipolysis in postoral and oral fat preferences in mice. American Journal of Physiology - Regulatory Integrative and Comparative Physiology, 315(3), R434-r441. doi:10.1152/ajpregu.00014.2018

Spielman, A. I., D'Abundo, S., Field, R. B., \& Schmale, H. (1993). Protein analysis of human von Ebner saliva and a method for its collection from the foliate papillae. Journal of dental research, 72(9), 1331-1335. doi: 10.1177\%2F00220345930720091301

Squires, B. T. (1953). Human salivary amylase secretion in relation to diet. Journal of Physiology, 119, 153-156. doi: 10.1113/jphysiol.1953.sp004835

Stewart, J. E., Feinle-Bisset, C., Golding, M., Delahunty, C., Clifton, P. M., \& Keast, R. S. (2010). Oral sensitivity to fatty acids, food consumption and BMI in human subjects. British Journal of Nutrition, 104(1), 145-152. doi:10.1017/s0007114510000267

Taylor, F. (1985). Flow-through pH-stat method for lipase activity. Analytical Biochemistry, 148(1), 149-153. doi: 10.1016/0003-2697(85)90639-6

Tiss, A., Lengsfeld, H., Carriere, F., \& Verger, R. (2009). Inhibition of human pancreatic lipase by tetrahydrolipstatin: Further kinetic studies showing its reversibility. Journal of Molecular Catalysis B-Enzymatic, 58(1-4), 41-47. doi:10.1016/j.molcatb.2008.11.003

Triantafyllou, A., Fletcher, D., \& Scott, J. (2003). Lipolytic and esterolytic activities in posterior lingual glands of rat: a histochemical study. The Histochemical Journal, 34(11), 529-533. doi:10.1023/a:1026037801958

Turini, P., Kurooka, S., Steer, M., Corbascio, A. N., \& Singer, T. P. (1969). The action of phenylmethylsulfonyl fluoride on human acetylcholinesterase, chymotyrpsin and trypsin. Journal of Pharmacology and Experimental Therapeutics, 167(1), 98-104.

Verger, R. (1997). 'Interfacial activation' of lipases: facts and artifacts. Trends in Biotechnology, 15(1), 32-38. doi: 10.1016/S0167-7799(96)10064-0 
640 Voigt, N., Stein, J., Galindo, M. M., Dunkel, A., Raguse, J. D., Meyerhof, W., . . Behrens, M. 641 (2014). The role of lipolysis in human orosensory fat perception. Journal of Lipid $642 \quad$ Research, 55(5), 870-882. doi:10.1194/jlr.M046029

643 Vors, C., Drai, J., Gabert, L., Pineau, G., Laville, M., Vidal, H., . . . Feron, G. (2015). Salivary 644 composition in obese vs normal-weight subjects: towards a role in postprandial lipid 645 metabolism? International Journal of Obesity, 39(9), 1425-1428. 646 doi:10.1038/ijo.2015.71

647

648

649

650

651

652

653 Figure caption:

654 Figure 1: overview of the research strategy

655 
Table 1 : References of the 17 selected articles

\section{Reference

Hamosh, M. (1978). Am J Physiol, 235(4), E416-421.

Méjean, C., Morzel, M., Neyraud, E., Issanchou, S., Martin, C., Bozonnet, S., . . Feron, G. (2015). PloS one, 10(9), e0137473.

Mennella, I., Fogliano, V., \& Vitaglione, P. (2014). Food Research International, 66, 463-468.

\section{Articles describing salivary lipolysis in relation to lipid digestion and metabolism}

Hamosh, M., \& Scow, R. O. (1973). J Clin Invest, 52(1), 88-95.

Plucinski, T. M., Hamosh, M., \& Hamosh, P. (1979). Am J Physiol, 237(6), E541-547.

Vors, C., Drai, J., Gabert, L., Pineau, G., Laville, M., Vidal, H., . . Feron, G. (2015). Int J Obes (Lond), 39(9), $1425-1428$.

\section{Articles describing salivary lipolysis in relation to lipid taste and preferences}

Besnard, P., Christensen, J. E., Brignot, H., Bernard, A., Passilly-Degrace, P., Nicklaus, S., ... Burcelin, R. (2018). Sci Rep, 8(1), 6742.

Kawai, T., \& Fushiki, T. (2003). Am J Physiol Regul Integr Comp Physiol, 285(2), R447-454.

Kulkarni, B. V., \& Mattes, R. D. (2014). Am J Physiol Regul Integr Comp Physiol, 306(12), R879-885.

Mounayar, R., Septier, C., Chabanet, C., Feron, G., \& Neyraud, E. (2013). Chemosensory Perception, 6(3), 118-126.

Neyraud, E., Palicki, O., Schwartz, C., Nicklaus, S., \& Feron, G. (2012). Arch Oral Biol, 57(5), 556-566.

Pepino, M. Y., Love-Gregory, L., Klein, S., \& Abumrad, N. A. (2012). J Lipid Res, 53(3), 561-566.

Poette, J., Mekoue, J., Neyraud, E., Berdeaux, O., Renault, A., Guichard, E., . . Feron, G. (2014). Flavour and Fragrance Journal, 29(1), 39-49.

Sclafani, A., \& Ackroff, K. (2018). Am J Physiol Regul Integr Comp Physiol, 315(3), R434-r441. 


\begin{tabular}{|c|c|c|c|c|}
\hline $\mathbf{N}^{\circ}$ & $\begin{array}{l}\text { Question/ } \\
\text { objective } \\
\text { sufficiently } \\
\text { described? }\end{array}$ & $\begin{array}{l}\text { Study design } \\
\text { evident and } \\
\text { appropriate? }\end{array}$ & $\begin{array}{l}\text { Outcome } \\
\text { measures(s) well } \\
\text { defined and } \\
\text { robust to } \\
\text { measurement/ } \\
\text { misclassification } \\
\text { bias? Means of } \\
\text { assessment } \\
\text { reported? }\end{array}$ & $\begin{array}{l}\text { Analytic methods } \\
\text { described/justifi } \\
\text { ed and } \\
\text { appropriate? }\end{array}$ \\
\hline
\end{tabular}

$\begin{array}{lllll}\begin{array}{l}\text { Some } \\ \text { estimate of }\end{array} & \begin{array}{l}\text { Results } \\ \text { reported }\end{array} & \begin{array}{l}\text { Conclusions } \\ \text { supported }\end{array} & \begin{array}{l}\text { Summary } \\ \text { Score }^{a}\end{array} & \text { Reason } \\ \end{array}$

variance is in

reported for sufficient

main results? detail?

Articles describing salivary lipolysis in relation to diet

\begin{tabular}{|c|c|c|c|c|c|c|c|c|c|}
\hline 1 & 1 & 1 & 0.5 & 1 & 1 & 1 & 1 & 0.9 & No control for lipase vs esterase \\
\hline 2 & 1 & 1 & 0.5 & 1 & 1 & 1 & 1 & 0.9 & No control for lipase vs esterase \\
\hline 3 & 1 & 1 & 1 & 1 & 1 & 1 & 1 & 1 & \\
\hline \multirow[t]{2}{*}{4} & 1 & 0.5 & 0.5 & 1 & 1 & 0.5 & 0.5 & 0.7 & $\begin{array}{l}\text { Control for lipase esterase not } \\
\text { specific enough. } \\
\text { pH for enzymatic evaluation far } \\
\text { from salivary pH } \\
\text { No quantitative data from } \\
\text { evaluation of products from } \\
\text { lipolysis by GC methodology }\end{array}$ \\
\hline & \multicolumn{9}{|c|}{ Articles describing salivary lipolysis in relation to lipid digestion and metabolism } \\
\hline 5 & 1 & 1 & 0.5 & 1 & 0.5 & 1 & 0.5 & 0.8 & No control for lipase vs esterase \\
\hline 6 & 1 & 0.5 & 0.5 & 0.5 & 1 & 1 & 1 & 0.8 & No control for lipase vs esterase \\
\hline 7 & 1 & 1 & 1 & 0.5 & 1 & 1 & 1 & 0.9 & $\begin{array}{l}\text { Methodology for lipolysis } \\
\text { measurement not detailed in } \\
\text { the paper, only a reference was }\end{array}$ \\
\hline
\end{tabular}


mentioned

\begin{tabular}{|c|c|c|c|c|c|c|c|c|c|}
\hline \multirow[b]{2}{*}{8} & \multicolumn{9}{|c|}{ Articles describing salivary lipolysis in relation to lipid taste and preferences } \\
\hline & 1 & 1 & 1 & 1 & 1 & 1 & 1 & 1 & \\
\hline 9 & 1 & 1 & 1 & 1 & 0.5 & 1 & 1 & 0.9 & $\begin{array}{l}\text { Results for lipase activity are in } \\
\text { abundance ratio of fatty acids } \\
\text { without standard deviation }\end{array}$ \\
\hline 10 & 1 & 1 & 1 & 1 & 1 & 0.5 & 0.5 & 0.9 & $\begin{array}{l}\text { No detailed statistics on sensory } \\
\text { values and their relations with } \\
\text { lipolysis }\end{array}$ \\
\hline 11 & 1 & 1 & 1 & 1 & 1 & 1 & 1 & 1 & \\
\hline 12 & 1 & 1 & 1 & 1 & 1 & 1 & 0.5 & 0.9 & $\begin{array}{l}\text { Indirect relationships (through } \\
\text { PCA analysis) between sensory } \\
\text { data and lipolysis, no direct } \\
\text { correlation. }\end{array}$ \\
\hline 13 & 1 & 0.5 & 1 & 1 & 1 & 0.5 & 1 & 0.9 & $\begin{array}{l}\text { No measure of lipolytic activity, } \\
\text { no description of the effect of } \\
\text { THL between the } 3 \text { groups of } \\
\text { obese subjects (the } 3 \text { groups } \\
\text { were polled) }\end{array}$ \\
\hline 14 & 1 & 1 & 1 & 1 & 1 & 1 & 1 & 1 & \\
\hline 15 & 1 & 1 & 1 & 1 & 1 & 1 & 1 & 1 & \\
\hline 16 & 1 & 0.5 & 0.5 & 0.5 & 0.5 & 0.5 & 0.5 & 0.6 & $\begin{array}{l}\text { No control for lipase vs esterase } \\
\text {, no detail regarding lipolytic } \\
\text { activity, no statistics between } \\
\text { lipolytic activity and sensitivity } \\
\text { to fat }\end{array}$ \\
\hline 17 & 1 & 1 & 1 & 1 & 1 & 1 & 1 & 1 & \\
\hline
\end{tabular}

661 aSummary score for each review was calculated by the total sum ((number of 'yes' scores $x 1)+($ number of 'partial' scores $x 0.5)+($ number of 662 'no' or 'not applicable' scores $\times 0$ )) divided by total possible score (7) 
664 Table 3: Descriptive analysis of the objectives and the methodology used for the lipolytic activity measurements in the 17 selected articles (NR: 665 not relevant)

\begin{tabular}{|c|c|c|c|c|c|c|c|c|}
\hline $\mathbf{N}^{\circ}$ & Objectives & $\begin{array}{l}\text { Lipase } \\
\text { activity } \\
\text { measured }\end{array}$ & $\begin{array}{l}\text { Control of } \\
\text { specificity }\end{array}$ & Biological material & Substrate & $\begin{array}{l}\mathrm{pH} \text { and } \mathrm{T}^{\circ} \text { of } \\
\text { measurement }\end{array}$ & $\begin{array}{l}\text { Methodology } \\
\text { for lipolysis } \\
\text { measurement }\end{array}$ & Model \\
\hline & \multicolumn{8}{|c|}{ Articles describing salivary lipolysis in relation to diet } \\
\hline 1 & $\begin{array}{l}\text { To study the adaptative response of } \\
\text { lingual lipase and pancreatic lipase } \\
\text { to dietary fat. }\end{array}$ & Yes & No & $\begin{array}{l}\text { Lingual tissue of } \\
\text { posterior part of the } \\
\text { tongue }\end{array}$ & Tributyrin & $\mathrm{pH} 5.4,37^{\circ} \mathrm{C}$ & Titration & Rats \\
\hline 2 & $\begin{array}{l}\text { To study the subcellular localization } \\
\text { of the lipase from the lingual serous } \\
\text { (Von Ebner) glands of rat tongue and } \\
\text { the factors affecting its activity (diet) } \\
\text { and secretion. }\end{array}$ & Yes & No & $\begin{array}{l}\text { Whole homogenate of } \\
\text { lingual serous (Von } \\
\text { Ebner) glands or } \\
\text { subcellular fractions }\end{array}$ & $\begin{array}{l}\text { Triglycerides } \\
\text { doubly } \\
\text { labelled }\left[2-{ }^{3} \mathrm{H}\right] \\
\text { glyceryl and }[\mathrm{l}- \\
\left.{ }^{14} \mathrm{C}\right] \text { tripalmitin }\end{array}$ & $\mathrm{pH} 5.4,37^{\circ} \mathrm{C}$ & Radiometry & Rats \\
\hline 3 & $\begin{array}{l}\text { To evaluate the association of } \\
\text { salivary flow and composition with } \\
\text { both preferences for fat, saltiness } \\
\text { and sweetness and the usual } \\
\text { nutrient intake in an adult French } \\
\text { population. }\end{array}$ & Yes & THL & $\begin{array}{l}\text { Clarified unstimulated } \\
\text { saliva }\end{array}$ & $\begin{array}{l}\text { 4-methyl- } \\
\text { umbelliferyl- } \\
\text { oleate }\end{array}$ & $\mathrm{pH} 7.5,37^{\circ} \mathrm{C}$ & Fluorescence & Human \\
\hline 4 & $\begin{array}{l}\text { To verify the relationships among } \\
\text { salivary lipase, } \alpha \text {-amylase activities } \\
\text { and zinc concentration with food } \\
\text { preference and choice of people } \\
\text { with different body mass indices. }\end{array}$ & Yes & PMSF & $\begin{array}{l}\text { Whole unstimulated } \\
\text { saliva }\end{array}$ & $\begin{array}{l}\text { 2,3- } \\
\text { Dimercapto-1- } \\
\text { propanol } \\
\text { tributyrate, } \\
\text { tripalmitin }\end{array}$ & $\begin{array}{l}\text { (1) } \mathrm{pH} 8.5 \\
37^{\circ} \mathrm{C} \quad(2) \mathrm{pH} \\
\text { of saliva } 37^{\circ} \mathrm{C}\end{array}$ & $\begin{array}{l}\text { Spectrophotom } \\
\text { etry and GC-FID }\end{array}$ & Human \\
\hline
\end{tabular}

\section{Articles describing salivary lipolysis in relation to lipid digestion and metabolism}




\begin{tabular}{|c|c|c|c|c|c|c|c|c|}
\hline 5 & $\begin{array}{l}\text { To study the secretory tissues of the } \\
\text { mouth of suckling and adult rats and } \\
\text { examine their lipolytic activity. }\end{array}$ & Yes & No & $\begin{array}{l}\text { Tissues from serous } \\
\text { glands of the tongue, } \\
\text { from the soft palate, } \\
\text { oral pharynx wall } \\
\text { including glands, } \\
\text { clarified unstimulated } \\
\text { saliva and stomach } \\
\text { content }\end{array}$ & $\begin{array}{l}{\left[1-{ }^{14} \mathrm{C}\right] \text { palmitic }} \\
\text { acid and } \\
\text { trioleoyl- }\left[2-{ }^{3} \mathrm{H}\right] \\
\text { glycerol, corn } \\
\text { oil } \\
\text { triglycerides, } \\
\text { and natural } \\
\text { milk fats }\end{array}$ & 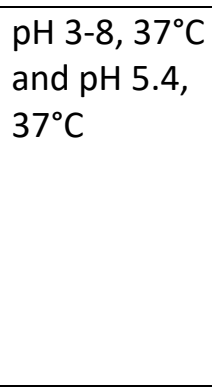 & $\begin{array}{l}\text { Radiometry and } \\
\text { titrimetry }\end{array}$ & Rats \\
\hline 6 & $\begin{array}{l}\text { To test the effect of oesophagus } \\
\text { ligation (i.e., absence of lingual } \\
\text { lipase) on intra-gastric triglyceride } \\
\text { hydrolysis and in the small intestine } \\
\text { of adults rats. }\end{array}$ & Yes & No & $\begin{array}{l}\text { Whole stimulated } \\
\text { food bolus }\end{array}$ & $\begin{array}{l}\text { Bovine milk- } \\
\text { cream mixture } \\
\text { with } 12 \text { to } 14 \% \\
\text { triglycerides }\end{array}$ & $\mathrm{pH} 5.4,37^{\circ} \mathrm{C}$ & $\begin{array}{l}\text { Titration and } \\
\text { GC-FID }\end{array}$ & Rats \\
\hline 7 & $\begin{array}{l}\text { To test the hypothesis that salivary } \\
\text { lipolysis differs according to BMI and } \\
\text { post-prandial lipid metabolism. }\end{array}$ & Yes & THL & $\begin{array}{l}\text { Clarified stimulated } \\
\text { saliva }\end{array}$ & $\begin{array}{l}\text { 4-Methyl- } \\
\text { umbelliferyl- } \\
\text { oleate }\end{array}$ & $\mathrm{pH} 7.5,37^{\circ} \mathrm{C}$ & Fluorescence & Human \\
\hline
\end{tabular}

\section{Articles describing salivary lipolysis in relation to lipid taste and preferences}

\begin{tabular}{|c|c|c|c|c|c|c|c|c|}
\hline 8 & $\begin{array}{l}\text { To test if subjects with obesity could } \\
\text { be characterized by an impaired } \\
\text { fatty taste sensitivity linked to a } \\
\text { change in the gustatory papillae in } \\
\text { the microbial and salivary } \\
\text { environment. }\end{array}$ & Yes & THL & $\begin{array}{l}\text { Clarified unstimulated } \\
\text { and stimulated saliva }\end{array}$ & $\begin{array}{l}\text { 4-Methyl- } \\
\text { umbelliferyl- } \\
\text { oleate }\end{array}$ & $\mathrm{pH} 7.5,37^{\circ} \mathrm{C}$ & Fluorescence & Human \\
\hline 9 & $\begin{array}{l}\text { To focus on the gustatory sense and } \\
\text { investigate the significance of the } \\
\text { lingual lipase released in the clefts of } \\
\text { foliate and vallate papillae, where } \\
\text { there are many taste bud cells, to } \\
\text { establish a link with the perception } \\
\text { of a fat taste. }\end{array}$ & Yes & THL & Tongues & $\begin{array}{l}\text { [carboxyl- }{ }^{14} \mathrm{C} \text { ] } \\
\text { triolein on } \\
\text { filter paper }\end{array}$ & NR & Radiometry & Rats \\
\hline
\end{tabular}


10 To determine the role of lingual

Yes

THL

Saliva in food bolus

Natural high-

NR

Human

lipase in oral fat detection as

fat food

dependent on the food matrix.

matrix:

almond,

almond

butter, olive

oil, walnut,

and coconut

\begin{tabular}{|c|c|c|c|c|c|c|c|c|}
\hline 11 & $\begin{array}{l}\text { To study whether saliva composition } \\
\text { is different in groups of subjects } \\
\text { having low or high oral sensitivity to } \\
\text { oleic acid. To determine whether } \\
\text { oral stimulation with oleic acid could } \\
\text { modify the composition of saliva. }\end{array}$ & Yes & $\mathrm{THL}$ & $\begin{array}{l}\text { Clarified unstimulated } \\
\text { and oleic acid } \\
\text { stimulated saliva }\end{array}$ & $\begin{array}{l}\text { 4-methyl- } \\
\text { umbelliferyl- } \\
\text { oleate }\end{array}$ & $\mathrm{pH} 7.5,37^{\circ} \mathrm{C}$ & Fluorescence & Human \\
\hline 12 & $\begin{array}{l}\text { To study intra- and inter-individual } \\
\text { variabilities over time in the } \\
\text { composition of molecules likely to } \\
\text { interact with food in the mouth, with } \\
\text { particular focus on molecules that } \\
\text { might interact with fat. }\end{array}$ & Yes & THL & $\begin{array}{l}\text { Clarified unstimulated } \\
\text { and stimulated saliva }\end{array}$ & $\begin{array}{l}\text { 4-methyl- } \\
\text { umbelliferyl- } \\
\text { oleate }\end{array}$ & $\mathrm{pH} 7.5,37^{\circ} \mathrm{C}$ & Fluorescence & Human \\
\hline 13 & $\begin{array}{l}\text { To evaluate whether a common } \\
\text { single nucleotide polymorphism } \\
\text { (rs1761667) in the CD36 gene that } \\
\text { reduces CD36 expression and the } \\
\text { addition of THL to reduce fatty acid } \\
\text { release from triacylglycerols would } \\
\text { attenuate fat orosensory sensitivity } \\
\text { in obese subjects. }\end{array}$ & No & THL & In situ study & Triolein & NR & NR & Human \\
\hline 14 & $\begin{array}{l}\text { To better understand how human } \\
\text { oral physiology may govern the } \\
\text { sensory sensitivity to non-esterified } \\
\text { fatty acids. }\end{array}$ & Yes & THL & $\begin{array}{l}\text { Clarified unstimulated } \\
\text { saliva }\end{array}$ & $\begin{array}{l}\text { 4-methyl- } \\
\text { umbelliferyl- } \\
\text { oleate }\end{array}$ & $\mathrm{pH} 7.5,37^{\circ} \mathrm{C}$ & Fluorescence & Human \\
\hline
\end{tabular}




\begin{tabular}{|c|c|c|c|c|c|c|c|c|}
\hline 15 & $\begin{array}{l}\text { To determine if fat preference is } \\
\text { influenced by the inhibition with } \mathrm{THL} \\
\text { of triglyceride lipolysis at both oral } \\
\text { and post-oral levels. }\end{array}$ & No & THL & In situ study & $\begin{array}{l}\text { Triolein, corn } \\
\text { oil, soybean oil }\end{array}$ & NR & NR & Mice \\
\hline 16 & $\begin{array}{l}\text { To investigate oral fatty acid } \\
\text { sensitivity, food selection and BMI in } \\
\text { human subjects. }\end{array}$ & Yes & No & $\begin{array}{l}\text { Clarified stimulated } \\
\text { saliva }\end{array}$ & $\begin{array}{l}\text { 1,2- } \\
\text { Diglycerides }\end{array}$ & $\mathrm{pH} 8,35^{\circ} \mathrm{C}$ & $\begin{array}{l}\text { Spectrophotom } \\
\text { etry }\end{array}$ & Human \\
\hline 17 & $\begin{array}{l}\text { To investigate whether triglycerides } \\
\text { represent an adequate "fatty" } \\
\text { stimulus in vivo and in vitro and to } \\
\text { determine if lipolytic enzymes are } \\
\text { present in the human oral cavity. }\end{array}$ & Yes & THL & $\begin{array}{l}\text { In situ study on } \\
\text { circumvallate papillae }\end{array}$ & Triolein & NR & HPLC-MS/MS & Human \\
\hline
\end{tabular}

667

668

669

670

671

672

673 
Table 4: Descriptive analysis of the main results about lipolytic activity and the associated parameters studied in the 17 selected articles (NR: not relevant)

\begin{tabular}{lll}
\hline $\mathbf{N}^{\circ} \quad$ Associated effects & Main results about lipolytic activity & $\begin{array}{l}\text { Main results of the association between the parameters studied and } \\
\text { lipolytic activity }\end{array}$
\end{tabular}

\section{Articles describing salivary lipolysis in relation to diet}

\begin{tabular}{llll}
\hline $\mathbf{1}$ & Level of fat in the diet & NR & $\begin{array}{l}\text { There is a positive adaptive response of the lingual lipase to the level } \\
\text { of fat in the diet. The type of fat has no effect on lipolytic activity. }\end{array}$ \\
\hline $\mathbf{2}$ & Level of fat in the diet & $\begin{array}{l}\text { Lingual lipase is located in the secretory } \\
\text { granules of the lingual serous (Von Ebner) } \\
\text { glands. } \\
\text { Lingual lipase secretion is stimulated by } \\
\text { isoprenaline. }\end{array}$ & $\begin{array}{l}\text { There is positive adaptive response of lipase lingual to the level of fat } \\
\text { in the diet. }\end{array}$ \\
\hline $\mathbf{3}$ & NR & & $\begin{array}{l}\text { Lipolysis is not associated with the intake of lipids, mono-unsaturated } \\
\text { or polyunsaturated and saturated fatty acids, whereas sensory } \\
\text { preference suggests the influence of saliva characteristics in food } \\
\text { acceptance. }\end{array}$ \\
\hline Lipid intake & NR & $\begin{array}{l}\text { Salivary lipolytic activity is higher in the overweight subjects than in } \\
\text { the normal weight subjects. } \\
\text { High salivary lipase activity in the overweight subjects may be an } \\
\text { adaptive response to the low-fat taste perception related to reduced } \\
\text { zinc concentration. }\end{array}$ \\
\hline
\end{tabular}

Articles describing salivary lipolysis in relation to lipid digestion and metabolism

\begin{tabular}{|c|c|c|c|}
\hline 5 & Fat digestion & $\begin{array}{l}\text { The lipase is secreted from serous gland } \\
\text { from the posterior part of the tongue and } \\
\text { fewly detected in the stomach. It is } \mathrm{pH} \\
\text { dependant. }\end{array}$ & $\begin{array}{l}\text { Salivary lipase contributes significantly to the digestion of triglyceride } \\
\text { in the stomach. }\end{array}$ \\
\hline
\end{tabular}




\begin{tabular}{|c|c|c|c|}
\hline 6 & Fat digestion & NR & $\begin{array}{l}\text { Lipolytic activity contributes significantly to the hydrolysis of fat } \\
\text { droplets not only in the stomach but also in the duodenum and the } \\
\text { ileum. }\end{array}$ \\
\hline \multirow[t]{2}{*}{7} & Lipaemia & NR & $\begin{array}{l}\text { Lipolysis in the obese subjects is significantly lower than in the normal } \\
\text { weight subjects and is associated with a delay in post-prandial } \\
\text { metabolism, as observed in the obese subjects compared to the } \\
\text { normal weight subjects. }\end{array}$ \\
\hline & \multicolumn{3}{|c|}{ Articles describing salivary lipolysis in relation to lipid taste and preference } \\
\hline 8 & $\begin{array}{l}\text { oleic acid detection } \\
\text { threshold }\end{array}$ & NR & $\begin{array}{l}\text { In the obese subjects, BMI is related to taste sensitivity, but no } \\
\text { association is observed between the sensitivity to oleic acid and } \\
\text { lipolytic activity in the obese subjects. Whatever the BMI, no link } \\
\text { between lipolysis and BMI is observed. }\end{array}$ \\
\hline 9 & Fat taste preference & $\begin{array}{l}\text { Lingual lipase is released continuously from } \\
\text { the papillae }\end{array}$ & $\begin{array}{l}\text { The addition of THL diminished the preference for triglycerides but } \\
\text { not for free fatty acids. Lingual lipase is involved in finding nutritive } \\
\text { lipids in food. }\end{array}$ \\
\hline 10 & Fat taste evaluation & NR & $\begin{array}{l}\text { THL inhibits the release of non-esterified fatty acids from the food } \\
\text { matrix in the food bolus and does not affect the sensory evaluation of } \\
\text { almond butter. }\end{array}$ \\
\hline 11 & oleic acid taste sensitivity & $\begin{array}{l}\text { Significant decrease in lipolytic activity is } \\
\text { observed after stimulation with oleic acid for } \\
\text { hypersensitive subjects }\end{array}$ & $\begin{array}{l}\text { No differences are found in the saliva characteristics according to } \\
\text { sensitivity to oleic acid. The oleic acid stimulation compared to a } \\
\text { control stimulation shows modified salivary composition in the } \\
\text { sensitive group only. No difference in lipolytic activity is observed } \\
\text { between the hypersensitive and hyposensitive subjects. }\end{array}$ \\
\hline 12 & Fat taste preference & $\begin{array}{l}\text { Subject salivary lipolysis is stable over time, } \\
\text { and no sampling effect was found. }\end{array}$ & $\begin{array}{l}\text { A positive relationship is found between the level of lipolysis and } \\
\text { fattiness, and a negative relationship for the level of lipolysis and } \\
\text { preference is observed. }\end{array}$ \\
\hline 13 & $\begin{array}{l}\text { oleic acid and triolein } \\
\text { orosensory } \\
\text { detection thresholds }\end{array}$ & NR & $\begin{array}{l}\text { The presence of THL decreases the sensitivity to triolein in obese } \\
\text { subjects. }\end{array}$ \\
\hline
\end{tabular}




\begin{tabular}{|c|c|c|c|}
\hline 14 & $\begin{array}{l}\text { oleic acid orosensory } \\
\text { detection threshold }\end{array}$ & $\begin{array}{l}\text { Subject salivary lipolysis is stable over time, } \\
\text { and no sampling effect is observed during 4- } \\
\text { month collection. }\end{array}$ & $\begin{array}{l}\text { Taste sensitivity to oleic acid is explained by the oral volume and the } \\
\text { level of lipolysis in saliva. The higher the lipolytic activity is, the higher } \\
\text { the threshold is. }\end{array}$ \\
\hline 15 & Fat taste preference & NR & $\begin{array}{l}\text { Inhibition of oral triglyceride hydrolysis leads to a decrease in } \\
\text { preferences for fat, but triglyceride hydrolysis is not essential for fat } \\
\text { preferences. }\end{array}$ \\
\hline 16 & $\begin{array}{l}\text { Orosensory detection } \\
\text { thresholds for oleic acid, } \\
\text { linoleic and lauric acids }\end{array}$ & NR & $\begin{array}{l}\text { Lipolytic level is sufficient to produce micromolar levels of fatty acids, } \\
\text { which can stimulate oral sensors. }\end{array}$ \\
\hline 17 & $\begin{array}{l}\text { Sensory sensitivity to triolein } \\
\text { or oleic acid }\end{array}$ & $\begin{array}{l}\text { Oleic acid is liberated from triglycerides } \\
\text { upon exposure to saliva secreted from } \\
\text { foliate papillae. THL reduces the generation } \\
\text { of oleic acid. } \\
\text { The expression of different lipases at the } \\
\text { level of the circumvallate papillae is } \\
\text { observed. Gene coding for lingual or gastric } \\
\text { lipase is not expressed in human lingual } \\
\text { tissue but genes coding for other lipases are } \\
\text { expressed. }\end{array}$ & $\begin{array}{l}\text { Triglyceride perception is attenuated by concomitant THL } \\
\text { administration. Lipolytic activities in minor salivary gland secretions } \\
\text { directly supplying gustatory papillae are correlated to individual } \\
\text { sensitivities for triglycerides. }\end{array}$ \\
\hline
\end{tabular}

680 


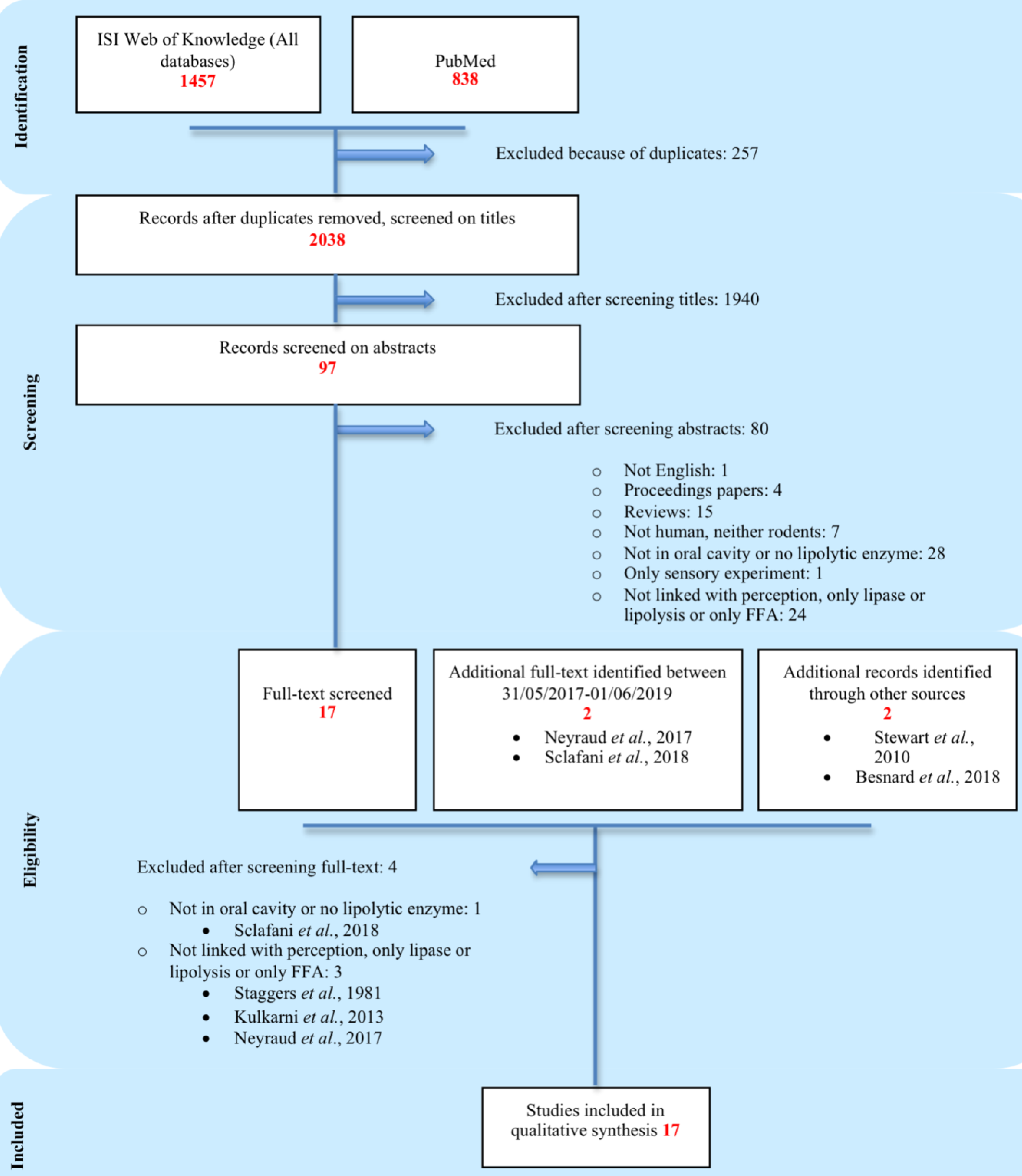

